\title{
Developing the Counselor Attitude Scale for Spirituality in Counseling: A Validity and Reliability Study
}

\author{
Figen Kasapoğlu ${ }^{1 \mathbb{C}}$
}

Asst. Prof., Department of Educational Sciences, Istanbul 29 Mayis University, Istanbul, Turkey. E-mail: figenkasapoglu.721@gmail.com.tr

Corresponding author:

Figen Kasapoğlu

E-mail:

figenkasapoglu.721@

gmail.com.tr

eISSN: $2458-9675$

Received: 13.11.2019

Revision: 05.05.2020

Accepted: 08.05.2020

CCopyright 2020

by Author(s)

\begin{abstract}
The purpose of this research is to develop the Counselor Attitude Scale for Spirituality in Counseling. The study group consists of 386 ( 253 female, 133 male) counselors. The methods of exploratory and confirmatory factor analyses are used to determine the construct validity of the scale. A single-factor structure consisting of seven items has been obtained as a result of the exploratory factor analysis. The compatibility the one-dimensional model has with the data is tested using confirmatory factor analysis. The single-factor model has been determined to have good fit indexes as a result of the analysis (RMSEA $=.04, \mathrm{RMR}=$ $.03, \mathrm{GFI}=.98, \mathrm{AGFI}=.95, \mathrm{CFI}=.99, \mathrm{IFI}=.99, \mathrm{NFI}=.98)$. Cronbach's alpha coefficient has been calculated as .89 for the reliability analysis of the scale and the test-retest coefficient as .88 ; the $27 \%$ lower-upper group t values are found to be significant $(p<.001)$. The findings show the developed scale to be psychometrically valid and reliable, and useful for assessing counselors' attitudes towards spirituality in counseling interactions.
\end{abstract}

Keywords: Counseling $\bullet$ Spirituality $\bullet$ Attitude $\bullet$ Scale development $\bullet$ Validity $\bullet$ Reliability

\section{Psikolojik Danışmada Maneviyata Yönelik Danışman Tutum Ölçeği' nin Geliştirilmesi: Geçerlik ve Güvenirlik Çalışması}

\section{Öz}

Bu araştırmanın amacı Psikolojik Danışmada Maneviyata Yönelik Danışman Tutum Ölçeği' nin geliştirilmesidir. Çalışma grubu 386 (253 kadın, 133 erkek) psikolojik danışmandan oluşmuştur. Ölçeğin yapı geçerliğini belirlemek için Açımlayıcı Faktör Analizi ve Doğrulayıcı Faktör Analizi yöntemi kullanılmıştır. Açımlayıcı Faktör Analizi sonucunda yedi maddeden oluşan tek faktörlü bir yapı elde edilmiştir. Tek boyutlu modelin veriye uyumu Doğrulayıcı Faktör Analizi ile test edilmiştir. Analiz sonucunda tek faktörlü modelin iyi uyum indekslerine sahip olduğu saptanmıştır (RMSEA =.04, RMR =.03, GFI=.98, AGFI=.95, CFI=.99, IFI=.99, NFI=.98). Ölçeğin güvenirlik analizlerinde hesaplanan Cronbach Alfa katsayısı .89; testtekrar test katsayısı .88 ve \%27'lik alt-üst grup t değerlerinin anlamlı olduğu $(p<.001)$ tespit edilmiştir. Sonuçlar, geliştirilen ölçeğin Türkiye'de psikolojik danışmanların danışma etkileşiminde maneviyata yönelik tutumlarını değerlendirmek amacıyla kullanılabilecek psikometrik açıdan geçerli ve güvenilir bir ölçek olduğunu göstermektedir.

Anahtar Kelimeler: Psikolojik Danışma • Maneviyat • Tutum• Ölçek Geliştirme • Geçerlik • Güvenirlik

Citation: Kasapoğlu, F. (2020). Developing the Counselor Attitude Scale for Spirituality in Counseling: A validity and reliability study. Spiritual Psychology and Counseling, 5, 219 - 236. https://dx.doi.org/10.37898/spc.2020.5.2.89 
Towards the end of the last century, the fields of psychotherapy and counseling noticed the need to address spiritual issues, and psychiatrists and psychologists began to address the subject of spirituality. Spirituality has been recognized as an important cultural phenomenon and coping factor that can affect counseling relationships, therapeutic processes, and outcomes over time (Gladding, 2013; Matise, Ratcliff, \& Mosci, 2018). Counseling is defined as "a professional relationship that empowers diverse individuals, families, and groups to accomplish mental health, wellness, education, and career goals" (Kaplan, Tarvydas, \& Gladding, 2014, p. 368). This definition has been endorsed by 29 major counseling organizations (American Counseling Association [ACA], n.d.). According to this definition, the counseling process covers practices for improving individuals' wellness. In this context, spirituality is among the life tasks of the wellness model developed by Myers, Sweeney, and Witmer (2000) in the field of counseling. Seligman (2007), one of the leading names in positive psychology, combined spirituality with psychology in his work on happiness and suggested that spiritual values inspire hope for the future and create meaning in life.

The Society for the Psychology of Religion and Spirituality, part of the American Psychological Association (APA), supports psychological theory, research, and clinical practice to ensure that people understand the importance of religion and spirituality in their lives and in the psychology discipline (APA, n.d.). Likewise, the Association for Spiritual, Ethical, and Religious Values in Counseling (ASERVIC), found within the ACA, works to integrate these values into the consultation process with the idea that spiritual, ethical, and religious values are necessary for people's general development (ASERVIC, 2017). Religion and spirituality were mainly included in the culture category in the Diagnostic and Statistical Manual of Mental Disorders, 5th Edition (DSM-5; American Psychiatric Association, 2013). Prusak (2016) stated that this increases the probability of differential diagnosis between religion/spirituality and health/psychopathology and that emphasis on cultural diversity provides a nonpathological perspective on the issues of religiosity and spirituality.

Spirituality seems to have a wide place and importance in many people's lives (ACA, 2015; Burke, Chauvin, \& Miranti, 2005; Cashwell \& Young, 2011; Johnson, 2013; Hook et al., 2019; Gladding \& Crockett, 2019; Morrison, Clutter, Pritchett, \& Demmitt, 2009; Steen, Engels, \& Thweatt, 2006; Young, Wiggins-Frame, \& Cashwell, 2007). Even those who do not believe in a higher power may conceptually have spiritual orientations and experiences (Matise et al., 2018). Whether clients define themselves as religious, spiritual, agnostic, or atheist, many clients carry experiences and beliefs about spirituality where more wellbeing can help or hinder this lifestyle (Lipka, 2016). In summary, directly or indirectly, spiritual issues have an important place in the lives of many individuals. 
Effective counseling handles the body, mind, and soul together (Corey, 2006). In this context, some researchers have recently considered being sensitive toward clients' spiritual aspects and taking these aspects into consideration to be one of the qualities of effective counselors (Moss \& Gloviak, 2017; Nystul, 2016; Oluseyi \& Oreoluwa, 2014). Thus, it is stated that the counselor and client's rapport will strengthen the therapeutic relationship (Moss \& Gloviak, 2017). Indeed, Takmaz (2017) in his study conducted in Turkey, stated that psychological counselors reported respecting clients' spirituality, creating a common language with clients, and not rejecting clients' spiritual statements in order not to damage clients' sense of trust.

For the counselor, including spirituality in counseling means (i) understanding the client's thoughts, feelings and behaviors; the core values that guide the client; and the client's psychological conflict; (ii) planning practices that the client is more likely to accept and that fit with their world view (thus increasing the likelihood of compliance); (iii) identifying the psychological barriers that prevent the client from potentially using powerful spiritual resources; and (iv) identifying the opportunity to strengthen the therapeutic relationship (Koenig \& Pritchett, 1998; Moss \& Gloviak, 2017). For clients, including spirituality in counseling allows them to define the meaning of life and access its essence (ACA, 2015). In this context, Hook et al. (2019) examined the effectiveness of adapting counseling and psychotherapy with respect to clients' spiritual values using a meta-analytical method and compared the effectiveness of psychotherapies adapted to spirituality with standard alternative psychotherapies. In the analyses, they found that psychotherapies adapted to spirituality resulted in more improvement in clients' psychological and spiritual functions compared to alternative standard psychotherapies. These results appear important for evidence-based therapeutic practices.

In the literature, research is seen to have been carried out on what thoughts and perceptions counselors have when dealing with spirituality, which has become more and more important in counseling practices (Adams, 2012; Bluemlein, 2003; Brown, Elkonin, \& Naicker, 2013; Burke, 2001; Chou \& Bermender, 2011; Cornish, Wade, \& Post, 2012; Ekşi, Takmaz, \& Kardaş, 2016; Francis, 2011; Frazier \& Hansen, 2009; Harper, 2012; Henriksen, Polonyi, Bornsheuer-Boswell, Greger, \& Watts, 2015; Hickson, Housley, \& Wages, 2000; Hofmann, 2009; Howard-Santana, 2006; Jenkins, 2009; Lawler, 2007; Lemkuil, 2007; Martin-Causey, 2001; Matthews, 2004; Morrison et al., 2009; Plumb, 2011; Rochow, 2002; Shafranske \& Malony, 1990; Sheridan, Bullis, Adcock, Berlin, \& Miller, 1992; Shuler, 2009; Smith, 2006; van Asselt \& Senstock, 2009; Weiss, 1999). Awareness of spirituality in counseling is explained as handling spiritual perspectives in an ethically appropriate and culturally sensitive way in the counseling process and in this context includes being sensitive toward: (i) establishing a spiritually clear and safe therapeutic relationship, (ii) setting spiritual goals in psychotherapy, (iii) making spiritual evaluations, (iv) following ethical rules, and (v) applying spiritual interventions appropriately in therapy (Richard \& Bergin, 2004, 2005). 
In the literature, various measurement tools have been developed to evaluate counseling perspectives for integrating spirituality into counseling (eg., Cornish et al., 2012; Hickson et al., 2000; Jenkins, 2009; Lemkuil, 2007; Morrison et al., 2009; Shafranske \& Malony, 1990; Shuler, 2009). For example, Lemkuil (2007) developed the Integration of Spirituality into Clinical Practice Questionnaire (ISCPQ) to measure the importance, perceived competence, and action beliefs of integrating spirituality into clinical practice in trauma cases. Jenkins (2009) developed the Scale of Comfort with Integrating Religion/Spirituality in Counseling (SCIRSC) to measure how comfortable counseling candidates feel about integrating religion and spirituality into counseling practices. Morrison et al. (2009) developed the Perceptions of Clients and Counseling Professionals Regarding Perceptions on Spirituality in Counseling Questionnaire (PPSCQ), as well.

When reviewing the literature in Turkey, no evidence of a measuring tool is found in the counseling process of counselors for assessing their perspectives on spirituality. Also, by considering the introduction of the "Spiritual Counseling" course in the Counseling and Guidance (CG) undergraduate programs (The Council of Higher Education, 2019), developing such a scale is thought necessary. As a matter of fact, in order to overcome the deficiency in this field, this study aims to develop a scale that assesses counselors' attitudes towards spirituality in counseling interactions.

\section{Method}

This research is a developmental study of a 5-point Likert-type attitude scale. The steps in Figure 1 have been followed for developing the scale (Büyüköztürk, Çakmak, Akgün, Karadeniz, \& Demirel, 2010, p. 106).

Figure 1.

Scale development steps.

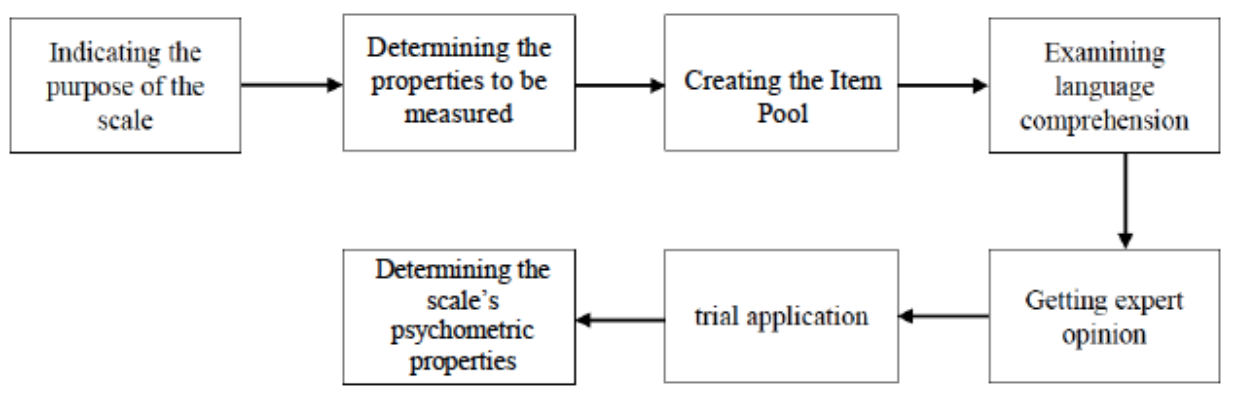

As can be seen in Figure 1, the first step is to identify the purpose of the measuring tool. The aim is to develop an attitude scale to be applied to counselors regarding how they handle spiritual issues in a sensitive and ethically appropriate manner in the counseling process. The scope of the features to be measured was determined for 
this, and an item pool was created. The language comprehensibility of the items was examined by a specialist in the field of Turkish language and literature. Subsequently, the item pool was presented to expert opinion in the field of psychological counseling. The items that needed removal and adjustment and those that could stay were determined in accordance with the experts' suggestions. Next, the items that remained were analyzed for validity and reliability, and the scale was finalized.

\section{Participants}

In scale development studies, one may work with participants whose attributes and numbers will allow the opportunity to perform statistical operations. In this case, the participants do not constitute the sample of the universe but the study group of the research (Can, 2019). In accordance with the purpose of the developed scale, the study group of this research consists of counselors who are Guidance and Counseling (GC) graduates. The study was carried out from February to April 2018. In this process, the data collection was attempted with two different groups. The first study group for the exploratory factor Analysis (EFA) consists of 180 people, and the second study group for confirmatory factor analysis (CFA) consists of 206 people.

Of the study group for the EFA, $112(62 \%)$ are female and $68(38 \%)$ are male; their average age is $31.13(S D=6.45) ; 122(62 \%)$ are university graduates, and $68(38 \%)$ have postgraduate educations. Thirty $(16.7 \%)$ people in the study group work in a primary school, $42(23.3 \%)$ in a secondary school, $33(18.3 \%)$ in a high school, 44 $(24.4 \%)$ in a guidance and research center, and $31(17.2 \%)$ in other institutions (e.g., university, private psychotherapy center).

For the CFA study group, 141 (68.4\%) are female and 65 (32.6\%) are male; their average age is $29.77(S D=7.05) .154(75 \%)$ are university graduates, and $52(25 \%)$ have postgraduate educations; 27 (13.1\%) people in the study group work in a primary school, 28 (13.6\%) in a secondary school, $19(9.2 \%)$ in a high school, $67(32.5 \%)$ in a guidance and research center, and $65(31.6 \%)$ in other institutions (e.g., university, private psychotherapy center).

\section{Data Collection Tools}

Demographic information form. This was designed by the researcher to determine participants' ages, gender, education level, institution, and the years of experience in the profession.

\section{Procedure}

The data were collected from February to April 2018 from counselors who are guidance and counseling graduates. The principle of volunteering was taken into 
consideration in selecting the participating group. Data collection was carried out in two ways. First, the service Google Forms was used. Collecting data was attempted for 30 days using Google Forms. In this process, feedback was received from 300 counselors. Later, the scale was applied face-to-face with counselors working in schools and guidance and research centers in Istanbul. Filling out the scale took about 10 minutes during the face-to-face interviews. At the end of this process, data had been collected from 412 counselors. After removing scales with missing or incorrect values $(n=26)$, analyses were performed on the remaining 386 pieces of data. The normality of the research data was examined using kurtosis and skewness coefficients. Each item was determined to have normal distribution with skewness and kurtosis values between -2.00 and 2.00 (George \& Mallery, 2019).

The construct validity of the developed scale was made with EFA and CFA. The principal component analysis technique is used in the EFA (Can, 2019). The suitability of the data for factor analysis has been examined with the Kaiser-Meyer-Olkin (KMO) and Bartlett Sphericity tests. The $K M O=.91$, which indicates that the sample size is sufficient for factor analysis of the data structure. According to the results from the Bartlett Sphericity Test, the chi-square value appears significant $\left(\chi^{2}=1680.776\right.$; $p<.01)$. These results indicate the data to be suitable for factor analysis. Following the EFA, CFA has been performed to evaluate the model's compliance with the data (Çokluk et al., 2014) using the $\chi^{2} / S D, R M S E A, R M R, G F I, A G F I, C F I, I F I$, and NFI fit indices. The reliability of the developed scale is examined using Cronbach's alpha, item-total correlations, lower-upper group analysis, and test-retest analysis.

\section{Findings}

First the literature related to the topic was searched in the process of developing the Counselor Attitude Scale for Spirituality in Counseling (CASSC). In this context, the ASERVIC-supported and ACA-approved spiritual competencies developed for counselors have been carefully examined (ASERVIC, 2015; Cashwell \& Watts, 2010; Robertson, 2008, 2010). In addition, the counseling approaches regarding spirituality have also been examined (eg., Curtis \& Davis, 1999; Elkins, 2015; Elkins, Hedstrom, Hughes, Leaf, \& Saunders, 1988; Hodge, 2006; Richards \& Bergin, 2004; Rizzuto \& Shafranske, 2013; Sperry \& Shafranske, 2005; Pargament, 2011; Tan \& Johnson, 2005; Tan, 2013; Thorne, 2012; White, 2000). Next, the data collection tools were examined that had been used in studies examining counselors' views on integrating spirituality during the counseling process (Adams, 2012; Bluemlein, 2003; Brown et al., 2013; Burke, 2001; Chou \& Bermender, 2011; Cornish et al., 2012; Francis, 2011; Henriksen et al., 2015; Hickson et al., 2000; Jenkins, 2009; Quillin, 2003; Lemkuil, 2007; Martinez, 2004; Matthews, 2004; Morrison et al., 2009; Plumb, 2011; Post, 2013; Shafranske \& Malony, 1990; Shuler, 2009; Smith, 2006; Weiss, 1999). Data 
was also collected at the same time by having the counselors write compositions. In this context, 23 professional counselors (10 females, 13 males; mean age $=34.1, S D$ $=7.2$ ) working at various school levels and universities have reported their views on spirituality in counseling by writing a composition. In addition, two focus group interviews were held. The focus group interviews are a series of planned interviews with a small group of participants on a predetermined topic and last between 1 and 2 hours (Patton, 2014). In this study, the interviews have been conducted with nine counselors ( 5 females, 4 males), with five in one group and four in the other. Each interview took about 60 minutes.

After the literature review and interviews, all the obtained information and data were evaluated together, and a pool of 49 expressions was created. The created item pool was sent to 13 experts in their field, and feedback was received from $12 \mathrm{GC}$ experts for evaluation. The feedback forms from the experts have been combined into one form. In accordance with the expert's suggestions, 34 items that were deemed insufficient, repetitive, and/or out of scope were excluded from the scale. In addition, 5 of the remaining 15 items were rearranged. The scale was reviewed by a language expert who determined it conformed to Turkish. In terms of pretesting, the form was carried out with 14 counselors working in different schools and guidance research centers for determining the understandability of the scale form and average response time. The items were rearranged based on the feedback received after the pretest application, and the trial application was made with 18 items. The concept of spirituality on the scale form was explained in accordance with its purpose, and the upper portion of the scale items were presented to the participants:

Spirituality is a phenomenon of human nature, which involves the search for a deep and constant meaning and realizing the longing for a reality beyond physical fineness. It is an innate capacity and trend for all people. This trend directs the individual towards knowledge, love, meaning, peace, hope, transcendence, devotion, compassion, goodness, and integrity. Spirituality covers a variety of facts, including experiences, beliefs, and practices (Association for Spiritual, Ethical, and Religious Values in Counseling, n.d., para. 1-2).

The scale was organized in the form of a 5-point Likert-type $(1=$ absolutely disagree, $5=$ completely agree) to reveal the counselors' views on addressing spiritual issues in counseling. The item pool consists of 14 positive and 4 negative items. The items are randomly ordered. While scoring the scale's items, the negative items are reverse scored.

The skewness and kurtosis coefficients, arithmetic means, standard deviations, and the lowest/highest scores of the scale items are presented in Table 1. 
Table 1.

Descriptive Statistics of Scale Items

\begin{tabular}{ccccccccc}
\hline Item no & $n$ & Lowest & Highest & $\bar{X}$ & SD & Skewness & Kurtosis & When the item is deleted $\alpha$ \\
\hline 1 & 180 & 1.00 & 5.00 & 4.09 & .95 & -1.08 & .89 & .91 \\
2 & 180 & 1.00 & 5.00 & 3.77 & .99 & -.41 & -.54 & .91 \\
3 & 180 & 1.00 & 5.00 & 3.70 & 1.08 & -.63 & -.32 & .90 \\
4 & 180 & 2.00 & 5.00 & 4.46 & .81 & -1.59 & 2.0 & .92 \\
5 & 180 & 2.00 & 5.00 & 4.23 & .87 & -.82 & -.29 & .91 \\
6 & 180 & 1.00 & 5.00 & 4.15 & .95 & -1.14 & 1.02 & .91 \\
7 & 180 & 1.00 & 5.00 & 3.41 & 1.21 & -.34 & -.92 & .91 \\
8 & 180 & 1.00 & 5.00 & 3.74 & .99 & -.63 & -.05 & .91 \\
9 & 180 & 1.00 & 5.00 & 3.21 & 1.13 & -.06 & -.81 & .91 \\
10 & 180 & 1.00 & 5.00 & 3.41 & 1.07 & -.23 & -.62 & .90 \\
11 & 180 & 1.00 & 5.00 & 3.79 & 1.14 & -.87 & .10 & .91 \\
12 & 180 & 1.00 & 5.00 & 3.62 & 1.03 & -.61 & -.18 & .91 \\
13 & 180 & 1.00 & 5.00 & 3.59 & 1.04 & -.54 & -.28 & .90 \\
14 & 180 & 1.00 & 5.00 & 3.29 & 1.22 & -.19 & -1.1 & .90 \\
15 & 180 & 1.00 & 5.00 & 3.03 & 1.21 & -.12 & -1.0 & .90 \\
16 & 180 & 1.00 & 5.00 & 3.36 & 1.27 & -.39 & -.90 & .91 \\
17 & 180 & 1.00 & 5.00 & 3.24 & 1.17 & -.29 & -.74 & .90 \\
18 & 180 & 1.00 & 5.00 & 3.22 & 1.26 & -.16 & -1.0 & .92 \\
\hline
\end{tabular}

Table 1 shows the scale items to have a lowest score of 1.00 (Items 4 and 5 had lowest scores of 2.00) and a highest score of 5.00; skewness coefficients range from -0.06 to -1.59 ; the kurtosis coefficients vary between -0.05 and 2.00. Skewness and kurtosis values show the distribution to be normal (George \& Mallery, 2019). Cronbach's alpha for the scale items is $\alpha=.91$. Looking at the values in the last column in Table 2, how Cronbach's alpha changes when an item is deleted is shown. In this case, when deleting Items 4 and 18, Cronbach's alpha is seen to increase to $\alpha$ $=.92$; EFA assesses whether or not these two items should be removed.

\section{Exploratory Factor Analysis Findings}

The analysis started with a total of 18 items. In EFA, whether or not to include an item in the scale depends on a high loading value, which indicates its relationship with the factor. Accordingly, an item must have a factor loading of at least 0.30 to be displayed on a factor. When an item's factor loading is between 0.30 and 0.60 , the item is concluded to measure the structure; this is at a high degree for items with factor loadings above 0.60 (positive or negative) (Kline, 1994). According to Tabachnick and Fidell (2013), 0.32 is the lowest acceptable limit. However, some theorists argue that this lowest acceptable factor loading should be 0.40 (Çokluk et al., 2014, p. 194). Kim-Yin (2004) proposed certain sample sizes to decide whether an expression should remain on the scale. For example, an item with a factor loading of 0.40 should have a sample size of at least 200 , and an item with a factor loading of 0.50 should have a sample size of at least 120 (as cited in Çokluk et al., 2014). In this study, the lower breakpoint for factor loading values is determined as 0.50 . 
In the analysis, eigenvalues being at least 1 has been decided upon in accordance with the Kaiser rule for each factor (Field, 2013). In the factor analysis, three factors with eigenvalues $>1$ were found (eigenvalues $=7.98,1.37$, and 1.17). These factors explain $58.39 \%$ of the total variance. In particular, the first factor was observed to explain a significant portion of the variance $(44.31 \%$, eigenvalue $=7.98)$. The screeplot graph has additionally been examined (Figure 2).

Figure 2.

Scree-plot graph.

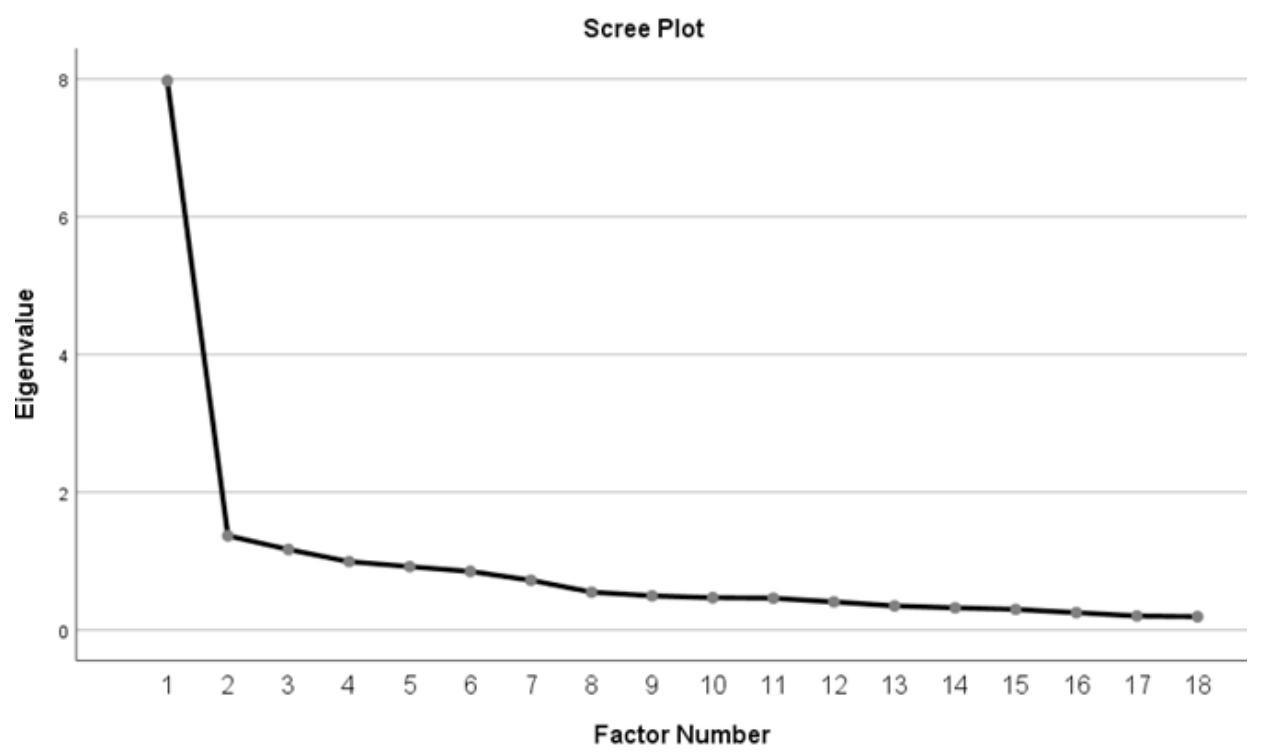

Figure 2 shows the slope to plateau after the second point. The contribution the factors after this point make to the variance is both small and approximately the same. This evidence indicates the scale to be one-dimensional. As a result of the analysis, the factor-loading values have been examined, and the analysis is repeated by deciding to individually remove Items $2,4,5,6$, and 18 , as their factor-loading values are below 0.50 .

Another important benchmark in EFAs is communalities. According to Erkuş (2012, p. 99), the common variance value is expected to be ".50 and greater for each item" when developing a scale. Common variances in the range of .50 are considered sufficient in sample sizes between 100 and 200 as long as the number of factors is relatively few and each has a very small number of indicator variables (Field, 2013, p. 1097). According to some researchers, the factorial solution obtained as a result of the analysis should explain at least half of the variance of each variable. Therefore, commonalities must be .50 or higher. For this reason, items with common variances less than .50 are recommended for removal from the analysis, and then the factor 
analysis is repeated (Şencan, 2005; Tabachnick \& Fidell, 2013; Yaşlığlu, 2017). Based on these points, factor analysis has been repeated here by subtracting Items 7 , $11,1,8,12$, and 9 , whose common variance values are less than .50 . Thus, the seven items in the single-factor scale explain $64.69 \%$ (eigenvalue $=4.53$ ) of the variance. Factor loading values and common variances for the seven items obtained as a result of the EFA are presented in Table 2.

Table 2.

EFA Results

\begin{tabular}{|c|c|c|c|}
\hline Item No & As a Counselor, ... & Factor loading & Common variances \\
\hline 15 & $\begin{array}{l}\text { I find it appropriate to use spiritual techniques in counseling } \\
\text { in addition to my basic theoretical counseling approach. }\end{array}$ & .82 & .68 \\
\hline 17 & $\begin{array}{l}\text { I find it appropriate to arrange therapy techniques to include } \\
\text { the client's spiritual perspective. }\end{array}$ & .81 & .66 \\
\hline 14 & $\begin{array}{l}\text { When the client's spiritual aspect is ignored, I think the con- } \\
\text { sultation process will be incomplete. }\end{array}$ & .78 & .61 \\
\hline 13 & $\begin{array}{l}\text { In the therapeutic context, I can refer to theories and current } \\
\text { research that support including the client's spiritual perspective. }\end{array}$ & .77 & .59 \\
\hline 16 & $\begin{array}{l}\text { I think there is a need for guidelines on the ethical inclusion } \\
\text { of spiritual content in counseling. }\end{array}$ & .75 & .56 \\
\hline 10 & $\begin{array}{l}\text { In order to evaluate the client in all aspects, I find it appro- } \\
\text { priate to consider the client's spirituality. }\end{array}$ & .73 & .53 \\
\hline 3 & $\begin{array}{l}\text { When setting goals in counseling, I consider the client's } \\
\text { spiritual perspective. }\end{array}$ & .70 & .50 \\
\hline
\end{tabular}

Table 2 shows the loading values of the items to vary between 0.70 and 0.82 and their common variances to range between 0.50 and 0.68 .

\section{Confirmatory Factor Analysis Findings}

CFA has been performed to test the goodness-of-fit of the single factor structure obtained through the EFA; the acceptance limits of the resulting fit-index values and good fit criteria are given in Table 3 (as cited in Meydan \& Şeşen, 2011, p.37).

Table 3.

Acceptance Limits of CFA Result and Fit Criteria

\begin{tabular}{cccc}
\hline Fit indices & Good Fit Index Values ** & Acceptable Fit Index Values * & CASSC \\
\hline$\chi 2 / s d$ & $\leq 3$ & $\leq 5$ & $1.26^{* *}$ \\
RMSEA & $\leq .05$ & $\leq .08$ & $.04^{* *}$ \\
RMR & $\leq .05$ & $\leq .08$ & $.03^{* *}$ \\
GFI & $\geq .90$ & $.89-.85$ & $.97^{* *}$ \\
AGFI & $\geq .90$ & $.89-.85$ & $.95^{* *}$ \\
CFI & $\geq .97$ & $\geq .95$ & $.99^{* *}$ \\
IFI & $\geq .95$ & $.94-.90$ & $.99^{* *}$ \\
NFI & $\geq .95$ & $.94-.90$ & $.97^{* *}$ \\
\hline
\end{tabular}

Table 3 shows the scale's index values to have good fit well. As a result of the CFA, the standardized coefficients of the model are given in Figure 3. 
Figure 3.

CFA standardized coefficient path diagram.

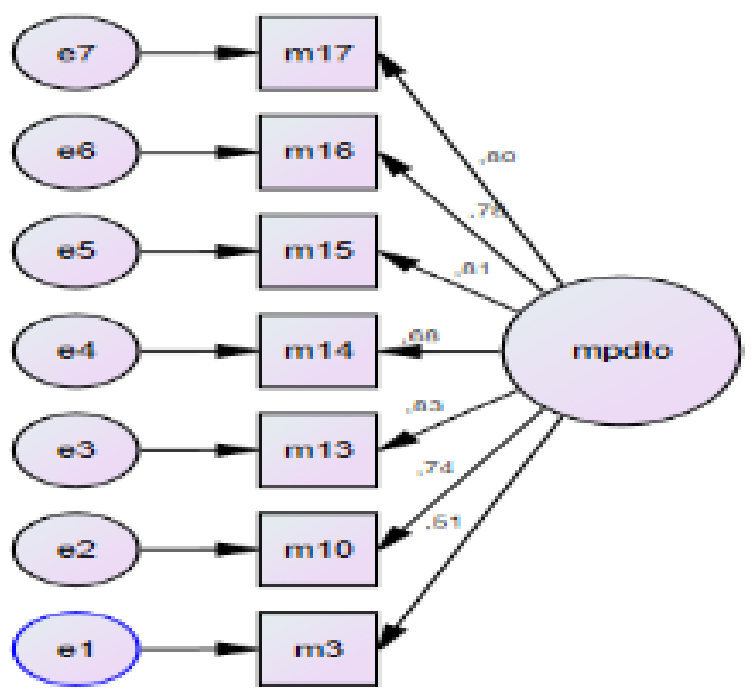

\section{Findings Regarding the Reliability of the CASSC}

Reliability analysis of the developed scale has been performed using Cronbach's alpha, item-total correlation coefficients, test-retest, and unrelated $t$-test method for the lower and upper $27 \%$ of the group. Cronbach's alpha for the scale is found as $\alpha=.89$. Scale reliability is interpreted as good for $\alpha>.70$; as such the scale has been interpreted as having good reliability (George \& Mallery, 2019). The item-total correlations and lower-upper 27\% $t$-test results from the scale are given in Table 4.

Table 4.

Item-Total Correlation of CASSC and Lower-Upper 27\% t-Test

\begin{tabular}{ccc}
\hline $\begin{array}{c}\text { Item } \\
\text { No }\end{array}$ & Item-total correlation & $\begin{array}{c}\mathrm{t} \\
\text { (Lower-Upper \%27) }\end{array}$ \\
\hline 1 & $.62^{* *}$ & $-8.60^{* * *}$ \\
2 & $.79^{* *}$ & $-15.11^{* * *}$ \\
3 & $.84^{* *}$ & $-14.80^{* * *}$ \\
4 & $.76^{* *}$ & $-13.70^{* * *}$ \\
5 & $.82^{* *}$ & $-17.82^{* * *}$ \\
6 & $.80^{* *}$ & $-18.99^{* * *}$ \\
7 & $.82^{* *}$ & $-15.83^{* * *}$ \\
\hline
\end{tabular}

$\mathrm{n}=206 ;$ Lower $\% 27=$ Upper\%27=55; **p $<0.01 ; * * * \mathrm{p}<0.001$.

Table 4 shows the item-total score correlations for all items in the scale to range between .62 and .84 and the $t$ values from the lower and upper $27 \%$ of the group to be significant $(p<.001)$. For the scale's test-retest reliability, 41 counselors $(24$ female, $58 \%$; 17 males, $42 \%$; average age $=32.39 ; S D=7.30$ ) were applied the scale twice at a three-week interval, and the test-retest reliability coefficient was calculated as $r$ $=.88$. These results can be interpreted as showing the items on the scale to be able to 
differentiate the attitudes of counselors towards spiritual issues during the counseling process and to be items aimed at measuring the same attitude.

As a result of the performed validity and reliability studies, the CASSC's usefulness is seen to be adequate. As a result, the scale is a 5-point Likert-type scale whose items are positively scored. The lowest obtainable score on the scale is 7 and the highest is 35. Obtaining higher scores on the scale shows counselors' attitudes towards handling spiritual issues in the therapeutic process to be more positive.

\section{Discussion}

This study has developed a scale for evaluating counselors' attitudes towards handling spirituality in the counseling process. According to the first finding of the study and as a result of the scale's EFA, a one-dimensional structure consisting of seven items has been obtained. The single factor of the scale explains $62.77 \%$ of the total variance. The total variance obtained from the analysis is considered sufficient as per "variance rates ranging from $40 \%$ to $60 \%$ can be accepted in the analysis made in the social sciences." (Tavşanc1l, 2014, p. 48). CFA has been performed to confirm the structure obtained as a result of the EFA. The model's compliance with the data has been performed by examining the fit indexes resulting from the CFA (Çokluk et al., 2014; Harrington, 2009; Meydan \& Şeşen, 2011). The fit-index values evaluated as a result of the CFA show good fit (Meydan \& Şeşen, 2011).

As a result of the scale's reliability analysis, the scale's items have been determined to be able to differentiate counselors' attitudes toward spirituality in the counseling process and to be items aimed at measuring the same attitude (Büyüköztürk, 2010; Can, 2019; De Vellis, 2003; George \& Mallery, 2019). The concurrent validity of the scale could not be tested as no similar scales exist. The results from the CASSC show it to be an appropriate scale that can be used to evaluate the attitudes of counselors toward spirituality in counseling activities.

In the literature, various measurement tools are seen to have been developed for evaluating counselors' views on integrating spirituality in counseling activities (Hickson et al., 2000; Jenkins, 2009; Lemkuil, 2007; Shafranske \& Malony, 1990; Shuler, 2009). For example, Lemkuil (2007) developed the ISCPQ to measure the importance, perceived efficacy, and activity beliefs therapists have for integrating spirituality in clinical practice in trauma cases; Jenkins (2009) developed the SCIRSC to measure how comfortable counselor candidates feel about integrating religion/ spirituality into counseling practices; and Morrison et al. (2009) similarly developed the PPSCQ. No evidence of counselors' perspectives on spirituality in the counseling process is found on any measurement tool for evaluation in Turkey. The CASSC developed in this research can be considered as an effort to overcome this deficiency. 
The CASSC developed in this research can be used to evaluate counselors' perspectives on spirituality in counseling practices. At the same time, when considering that the "Spiritual Counseling" course has been included in the undergraduate curriculum for guidance and counseling since 2019, the scale as such is believed to be able to be used in the regulation and implementation stages of the undergraduate education programs for training candidates to be better equipped. Additionally, performing different research in the field of counseling using the CASSC is considered possible and thus can contribute to the field.

\section{Acknowledgement}

The application was made with the approval of the Inonu University Scientific Research and Publication Ethics Committee (2017/16-2), and with official permission (2017/ 19883342).

This study is a part of the doctoral thesis 'Examination of counselors' attitudes towards spirituality in counseling spiritual orientation and effective counselor characteristics" under the supervision of Prof. Dr. Mustafa Kutlu.

The working stages follow the principles set out in the Helsinki Declaration.

\section{References}

Adams, J. R. (2012). Spiritual issues in counseling: What do students perceive they are being taught? Counseling and Values, 57(1), 66-80. doi:org/10.1002/j.2161-007X.2012.00009.x

American Counseling Association. (2014). Code of ethics. Retrieved from https://www.counseling. org/resources/aca-code-of-ethics.pdf

American Counseling Association. (2015). The ACA encyclopedia of counseling (pp. 517-521). John Wiley \& Sons. doi:10.1002/9781119221548.ch19

American Counseling Association. (n.d.). 20/20: Consensus definition of counseling. Retrieved from https://www.counseling.org/about-us/about-aca/20-20-a-vision-for-the-future-of-counseling/ consensus-definition-of-counseling

American Psychiatric Association. (2013). Diagnostic and statistical manual of mental disorders (DSM-5). Arlington: American Psychiatric Publishing.

American Psychological Association. (n.d.). About society for the psychology of religion and spirituality. Retrieved from https://www.apadivisions.org/division-36/about

Association for Spiritual, Ethical and Religious Values in Counseling. (2017). Bylaws. Retrieved from http://www.aservic.org/wp-content/uploads/2018/07/ASERVIC-2017-Bylaws-Revised-316-17-ACA-Approved-10-2017-1.pdf

Association for Spiritual, Ethical and Religious Values in Counseling. (2015). Spiritual competencies: Competencies for addressing spiritual and religious issues in counseling. Retrieved from http:// www.aservic.org/resources/spiritual-competencies/

Bluemlein, J. S. (2003). Professional helpers' perceptions of spirituality in the counseling process (Unpublished doctoral dissertation). University of Cincinnati, Ohio. 
Brown, O., Elkonin, D., \& Naicker, S. (2013). The use of religion and spirituality in psychotherapy: Enablers and barriers. Journal of religion and health, 52(4), 1131-1146. doi:10.1007/s10943-011-9551-z

Burke, J. F. (2001). Dealing with issues of spirituality when they emerge in the counseling process (Unpublished doctoral dissertation). Fordham University, New York.

Burke, M. T., Chauvin, J. C., \& Miranti, J. G. (2005). Religious and spiritual issues in counseling: Applications across diverse populations. New York: Brunner-Routledge.

Büyüköztürk, Ş. (2010). Sosyal bilimler için veri analizi el kitabı (12. bas.). Ankara: Pegem Akademi.

Büyüköztürk, Ş., Çakmak, E.K., Akgün, Ö.E., Karadeniz, Ş., \& Demirel F. (2010). Bilimsel araştırma yöntemleri (5. bas.). Ankara: Pegem Akademi.

Byrne, B. M. (2010). Structural equation modeling with AMOS: Basic concepts, applications, and programming. Routledge.

Can, A. (2019). SPSS ile bilimsel araştırma sürecinde nicel veri analizi (7. bas.). Ankara: Pegem Akademi.

Cashwell, C. S. \& Watts, R. E. (2010). The new ASERVIC competencies for addressing spirirtual and religious issues in counseling. Counseling and Values, 55(1), 2-5. doi.org/10.1002/j.2161007X.2010.tb00018.x

Cashwell, C. S. \& Young, J. S. (2011). Integrating spirituality and religion into counseling: An introduction. In C. S. Cashwell and J. S. Young (Eds.), Integrating spirituality and religion into counseling: A guide to competent practice (2 ${ }^{\text {nd }}$ ed., pp. 1-24). Alexandria, VA: American Counseling Association.

Chou, W. M. \& Bermender, P. A. (2011). Spiritual integration in counseling training: A study of students' perceptions and experiences. Erişim adresi: http://counselingoutfitters.com/ vistas/ vistas11/Article_98.pdf

Corey, G. (2006). Integrating spirituality in counseling practice. Journal Vistas, 6, 117-119. Retrieved from https://www.counseling.org/docs/default-source/vistas/integrating-spiritualityin-counseling-practice.pdf?sfvrsn=10

Cornish, M. A., Wade, N. G., \& Post, B. C (2012). Attending to religion and spirituality in group counseling: Counselors' perceptions and practices. Group Dynamics: Theory, Research and Practice, 16(2), 122-137. doi/10.1037/a0026663

Curtis, R. C. \& Davis, K. M. (1999). Spirituality and multimodal therapy: a practical approach to incorporating spirituality in counseling. Counseling and Values, 43, 199-210. doi.org/10.1002/ j.2161-007X.1999.tb00143.x

Çokluk, Ö, Şekercioğlu, G., \& Büyüköztürk, Ş. (2014). Çok değişkenli İstatistik (3. bas.). Ankara: Pegem Akademi.

Dailey, S. F., Curry, J. R., Harper, M. C., Hartwig Moorhead, H. J., \& Gill, C. S. (2011). Exploring the spiritual domain: Tools for integrating spirituality and religion in counseling. Retrieved from http://counselingoutfitters.com/vistas/vistas11/Article_99.pdf

DeVellis, R. F. (2016). Scale development theory and applications ( $4^{\text {th }}$ ed.). California: SAGE Publications.

Ekşi, H., Takmaz,Z., \& Kardaş, S. (2016). Spirituality in psychotherapy settings: A phenomenological inquiry into the experiences of Turkish health professionals. Spiritual Psychology and Counseling, 1, 89-108. doi:org/10.12738/spc.2016.1.0005

Elkins, D. N. (2015). Beyond religions: Toward a humanist spirituality. In K. J. Schneider, J. F. Pierson, and J. F. T. Bugental (Eds.). The handbook of humanistic psychology: Theory, research, and practice ( $2^{\text {nd }}$ ed., pp. 681-692). Thousand Oaks, CA: Sage. 
Elkins, D. N., Hedstrom, L. J., Hughes, L. L., Leaf, J. A., \& Saunders, C. (1988). Toward a humanistic-phenomenological spirituality. Journalof Humanistic Psychology, 28, 5-18. doi:or $\mathrm{g} / 10.1177 \% 2 \mathrm{~F} 0022167888284002$

Erkuş, A. (2012). Psikolojide ölçme ve ölçek geliştirme-I. Ankara: Pegem Akademi.

Field, A. (2013). Discovering statistics using IBM SPSS statistics $\left(4^{\text {th }}\right.$ ed.). SAGE Publications Ltd.

Francis, J. (2011). Religious and spiritual beliefs, practices, professional attitudes and behaviors of clinical and counseling psychology interns (Unpublished doctoral dissertation). Pepperdine University.

Frazier, R. E., \& Hansen, N. D. (2009). Religious/spiritual psychotherapy behaviors: Do we do what we believe to be important? Professional Psychology: Research and Practice, 40(1), 8196. doi:10.1037/a0011671

George, D. \& Mallery, M. (2019). SPSS for windows step by step: A simple guide and reference 17.0 update (15. ed.). Routledge.

Gladding, S. T. (2013). Psikolojik danışma (N. Voltan Acar, Çev.). Ankara: Nobel Yayıncılık.

Gladding, S. T. \& Crockett, J. E. (2019). Religious and spiritual issues in counseling and therapy: Overcoming clinical barriers. Journal of Spirituality in Mental Health, 21(2), 152-161. doi.org/ 10.1080/19349637.2018.1476947

Harper, D. M. (2012). Influences of five counseling psychologists'spiritual and religious views on their identity and role as counseling psychologists in practice (Unpublished doctoral dissetation). New Mexico State University Las Cruces, New Mexico.

Harrington, D. (2009). Confirmatory factor analysis. Oxford University Press.

Henriksen Jr., R. C., Polonyi, M. A., Bornsheuer-Boswell, J. N., Greger, R. G., \& Watts, R. E. (2015). Counseling students' perceptions of religious/spiritual counseling training: A qualitative study. Journal of Counseling ve Development, 93, 59-69. doi:org/10.1002/j.1556-6676.2015.00181.x

Hickson, J., Housley, W., \& Wages, D. (2000). Counselor's perceptions of spirituality in the therapeutic process. Counseling and Values, 45, 58-66. doi:org/10.1002/j.2161-007X.2000.tb00183.x

Hodge, D. R. (2006). Spiritually Modified Cognitive Therapy: A Review of the Literature. Social Work, 51(2), 157-166. doi:org/10.1093/sw/51.2.157

Hofmann, L. I. (2009). Spiritualität und Religiosität in der psychotherapeutischen Praxis. Eine bundesweite Befragung von Psychologischen Psychotherapeuten (Unpublished doctoral dissertation). Carl von Ossietzky Universität, Oldenburg.

Hook, J. N., Captari, L. E., Hoyt, W., Davis, D. E., McElroy, S. E., \& Worthington Jr., E. L. (2019). Religion and spirituality. In J. C., Norcross, (Ed.). Psychotherapy relationships that work: Therapist contributions and responsiveness to patients ( $3^{\text {rd }}$ ed., pp. 212-263). New York, US: Oxford University Press.

Howard Santana, N. İ. (2006). Qualitative study of the psychologists' perspectives of discussing spiritual issues in therapy (Unpublished doctoral dissertation). California School of Professional Psychology at Alliant International University, San Diego.

Jenkins, C. A. (2009). Measuring comfort level of counselors-in-training with integrating religion/ spirituality in counseling (Unpublished master thesis). Southern Illinois University, Carbondale.

Johnson, R. (2013). Spirituality in counseling and psychotherapy. Hoboken, NJ: John Wiley.

Johnson, R. A. \& Wichern, D. W. (2007). Applied multivariate statistical analysis. New Jersey: Prentice-Hall. 
Kaplan, D. M, Tarvydas, V. M., \& Gladding, S. T. (2014). 20/20: A vision for the future of counseling: The new consensus definition of counseling. Journal of Counseling and Development, 92, 366-372. doi:org/ 10. 1002/j.1556-6676.2014.00164.x

Kelly, V. A. (2009). Factor analysis. The ACA encyclopedia of counseling, (pp.194-195). ACA.

Kline, P. (1994). An easy guide to factor analysis. Newyork: Routledge.

Koenig, H. G. \& Pritchett, J. (1998). Religion and psychotherapy. In H. G. Koenig (Ed.), Handbook of religion and mental health (pp. 323-364). San Diego, CA: Academic Press.

Lawler, M. A. (2007). An exploration of therapists' perception of personal and professional spirituality (Unpublished doctoral dissertation). Capella University, Minneapolis.

Lemkuil, J. L. (2007). Integration of spirituality into clinical practice (Unpublished doctoral dissertation). The University of Wisconsin-Milwaukee.

Lines, D. (2006). Spirituality in counselling and psychotherapy. London: SAGE Publications.

Lipka, M. (2016). “Why America's 'Nones’ Left Religion Behind.” Pew Research Center. Retrieved from http://www.pewresearch.org/fact-tank/2016/08/24/why-americas-nones-left-religion-behind/

Martin-Causey, T. (2001). Spirituality as a multicultural consideration: Implications for practice and training (Unpublished doctoral dissertation). New Mexico State University Las Cruces, New Mexico.

Martinez, J. S. (2004). Spiritual interventions in psychotherapy: client perspectives (Unpublished doctoral dissertation). Brigham Young University, Utah.

Matthews, P. J. (2004). Spirituality and self-efficacy in counseling and social work trainees (Unpublished doctoral dissertation). University of Arkansas, Arkansas.

Matise, M., Ratcliff, J., \& Mosci, F. (2018). A working model for the integration of spirituality in counseling. Journal of Spirituality in Mental Health, 20(1), 27-50. doi:o $\mathrm{rg} / 10.1080 / 19349637.2017 .1326091$

Meydan, C. H. \& Şeşen, H. (2011). Yapısal eşitlik modellemesi AMOS uygulamaları. Ankara: Detay Yayıncilık.

Morrison, J. Q., Clutter, S. M., Pritchett, E. M., \& Demmitt, A. (2009). Perceptions of clients and counseling professionals regarding spirituality in counseling. Counseling and Values, 53, 183194. doi:org/10.1002/j.2161-007X.2009.tb00124.x

Moss, R. \& Glowiak, M. V. (2017). The therapeutic alliance and the helping relationship. In D. Capuzzi and D. R. Gross (Eds.), Introduction to the counseling profession ( $7^{\text {th }}$ ed., pp. 145-166). Routledge.

Myers, J. E., Sweeney, T. J., \& Witmer, J. M. (2000). The wheel of wellness counseling for wellness: A holistic model for treatment planning. Journal of Counseling and Development, 78(3), 251266. doi:org/10.1002/j.1556-6676.2000.tb01906.x

Nystul, M. S. (2016). Introduction to counseling: An art and science perspective ( $5^{\text {th }}$ ed.). Sage Publications.

Oluseyi, A. E. ve Oreoluwa, S. V. (2014). Factorial Composition of Counsellor Effectiveness Scale. World Journal of Education, 4(4), 61-69.

Pargament, K. I. (2011). Spiritually integrated psychotherapy: Understanding and addressing the sacred. New York: The Guilford Press.

Patton, M. Q. (2014). Nitel araştırma ve değerlendirme yöntemleri (M. Bütün ve S. B. Demir, Çev.). Ankara: PEGEM Akademi.

Plumb, A. M. (2011). Spirituality and counselling: Are counsellors prepared to integrate religion and spirituality into therapeutic work with clients? Canadian Journal of Counselling and Psychotherapy/Revue canadienne de counseling et de psychothérapie, 45(1), 1-16. 
Post, B. C. (2013). Religious and spiritual issues in group counseling: Beliefs and preferences of university counseling center clients and therapists (Unpublished doctoral dissertation). Iowa State University.

Prusak, J. (2016). Differential diagnosis of "religious or spiritual problem" —Possibilities and limitations implied by the V-code 62.89 in DSM-5. Psychiatria polska, 50(1), 175-186. Retrieved from https://www.ncbi.nlm.nih.gov/pubmed/27086337

Quillin, A. B. (2003). Perceptions of the spiritual: an assessment of master's level student counselors' views of spirituality (Unpublished Doctoral dissertation). Kent State University, Ohio.

Richards, P. S. \& Bergin, A. E. (2004). Casebook for a spiritual strategy for counseling and psychotherapy. Washington, DC: American Psychological Association.

Richards, P. S. \& Bergin, A. E. (2005). A spiritual strategy for counseling and psychotherapy ( $2^{\text {nd }}$ ed.). Washington, DC: American Psychological Association. doi:10.1037/11214-000

Rizzuto, A.-M. \& Shafranske, E. P. (2013). Addressing religion and spirituality in treatment from a psychodynamic perspective. In K. I. Pargament (Ed.). APA handbook of psychology, religion and spirituality: Vol. 2. An applied psychology of religion and spirituality (pp. 125-146). Washington DC: American Psychological Association. doi: 10.1037/14046-006

Robertson, L. A. (2008). The spiritual competency scale: A comparison to the ASERVIC spiritual competencies (Unpublished Doctoral dissertation). University of Central Florida Orlando, Florida.

Robertson, L. A. (2010). The Spiritual Competency Scale. Counseling and Values, 55(1), 6-24.

Rochow, S. (2002). Religion and spirituality within counselling (Unpublished master thesis). Calgary, Alberta, Kanada.

Seligman, M. E. P. (2007). Gerçek mutluluk (çev. S. Kunt Akbaş). Ankara: Hyb Yayıncılık.

Shafranske, E. P. \& Malony, H. N. (1990). Clinical psychologists' religious and spiritual orientations and their practice of psychotherapy. Psychotherapy, 27, 72-78.

Sheridan, M. J., Bullis, R. K., Adcock, C. R., Berlin, S. D., \& Miller, P. C. (1992). Practitioners' personal and professional attitudes and behaviors toward religion and spirituality: Issues for education and practice. Journal of Social Work Education, 28(2), 190-203. doi:o $\mathrm{rg} / 10.1080 / 10437797.1992 .10778772$

Shuler, M. K. (2009). The influence of spiritual development on counselor beliefs about the role of religion and spirituality in counseling (Unpublished doctoral dissertation). The University of Texas at San Antonio.

Smith, J. D. (2006). Rehabilitation counselor willingness to integrate spirituality into client counseling session. (Unpublished doctoral dissertation). State University of New York.

Sperry, L. \& Shafranske, E. P. (2005). (Eds.). Spiritually oriented psychotherapy. Washington DC: American Psychological Association. doi:org/10.1037/10886-000

Steen, R. L., Engels, D., \& Thweatt, W. T., III. (2006). Ethical aspects of spirituality in counseling. Counseling and Values, 50, 108-117. doi:org/10.1002/j.2161-007X.2006.tb00047.x

Suhr, D. D. (2006). Exploratory or confirmatory factor analysis? (pp. 1-17). In. Cary: SAS Institute. Şencan, H. (2005). Sosyal ve davranışsal ölçümlerde güvenilirlik ve geçerlilik. Ankara: Hüner Şencan. Tabachnick, B. G. \& Fidell, L. S. (2013). Using multivariate statistics (6 $6^{\text {th }}$ ed.). Pearson Education. Takmaz, Z. (2017). Psikolojik danışma etkileşiminde maneviyata bakış: Nitel bir çalışma (Yayınlanmamış yüksek lisans tezi). Marmara Üniversitesi Eğitim Bilimleri Enstitüsü, İstanbul. Retrieved from https://tez.yok.gov.tr/UlusalTezMerkezi/ 
Tan, S. Y. (2013). Addressing religion and spirituality from a cognitive-behavioral perspective. In K. I. Pargament (Ed.). APA Handbook of Psychology, Religion and Spirituality: Vol. 2. An Applied Psychology of Religion and Spirituality (pp. 169-187). Washington DC: American Psychological Association. doi: 10.1037/14046-008

Tan, S. Y. \& Johnson, W. B. (2005). Spirituality oriented cognitive-behavioral therapy. In Sperry, L., and Shafranske, E. P. (Ed.). Spiritually oriented psychotherapy (pp. 77-103). Washington DC: American Psychological Association.

Tavşancıl, E. (2014). Tutumların ölçülmesi ve SPSS ile veri analizi (5. bas.). Ankara: Nobel Yayın Dağıtım.

The Council of Higher Education. (2019). Rehberlik ve psikolojik danışmanlık lisans programı. Retrieved from https:/www.yok.gov.tr/Documents/Kurumsal/egitim_ogretim_dairesi/Yeni-Ogretmen-Yetistirme-Lisans-Programlari/Rehberlik_ve_Psikolojik_Danismanlik_Lisans_Programi.pdf

Thorne, B. (2012). Counselling and spiritual accompaniment: Bridging faith and person-centred therapy. John Wiley and Sons, Ltd.

van Asselt, K. W. \& Senstock, T. D. B. (2009). Influence of counselor spirituality and training on treatment focus and self-perceived competence. Journal of Counseling and Development, 87(4), 412-419. doi:org/10.1002/j.1556-6678.2009.tb00125.x

Weiss, J. F. (1999). A qualitative investigation of counseling students' attitudes toward addressing spiritual issues in counseling (Unpublished doctoral dissertation). The University of Georgia.

White, M. (2000). Exploring notions of spirituality and religion. An interview with Dave Spellman. Context, 48, 5-9.

Yaşlığlu, M. M. (2017). Sosyal bilimlerde faktör analizi ve geçerlilik: Keşfedici ve doğrulayıcı faktör analizlerinin kullanılması. İstanbul Üniversitesi Işletme Fakültesi Dergisi, 46 (Special Issue), 74-85.

Young, J., Wiggins-Frame, M., \& Cashwell, C. S. (2007). Spirituality and counselor competence: A national survey of American Counseling Association members. Journal of Counseling and Development, 85,47-52. doi:org/10.1002/j.15566678.2007.tb00443.x 